\title{
The Effect of Litter Size on Ewe and Their Lamb Performances under Intensive Management System
}

\author{
Diahanvika Tri Sarvinda $^{1}$, Sigit Bintara ${ }^{2}$, I Gede Suparta Budisatria ${ }^{3}$, Kustantinah \\ Kustantinah $^{4}$ and Endang Baliarti ${ }^{*}$
}

\author{
${ }^{1}$ Student, Faculty of Animal Science, Universitas Gadjah Mada, Indonesia-55281 \\ 2 Department of Animal Breeding and Reproduction, Faculty of Animal Science, Universitas Gadjah Mada, \\ Indonesia-55281 \\ ${ }^{3}$ Department of Animal Production, Faculty of Animal Science, Universitas Gadjah Mada, Indonesia-55281 \\ ${ }^{4}$ Department of Animal Nutrition, Faculty of Animal Science, Universitas Gadjah Mada, Indonesia-55281 \\ *Corresponding author. Email: bali_arti@ugm.ac.id
}

\begin{abstract}
This study aims to determine the effect of litter size of ewes and lamb performances under an intensive care management system. The material used was 20 ewes consisting of single and twin litter sizes given the same rations. Ewes were kept in individual cages from four months of gestation to one month postpartum. The variables observed were ewe's consumption, body weight, Body Condition Score (BCS), birth weight, and Average Daily Gain (ADG). Data were analyzed using one-way ANOVA (SPSS ver. 22). The results showed that the consumption of DM, CP was significantly different $(\mathrm{P}<0.05)$. The bodyweight of gestation, parturition, and one month after lambing ewes between litter sizes were not significantly different $(\mathrm{P}>0.05)$. Ewes BCS significantly affected the performances of single and twin litter sizes (gestation; $3.12 \pm 0.24$ vs. $2.83 \pm 0.29$ and one month after lambing; $2.82 \pm 0.25$ vs. $2.50 \pm 0.00$ ). The total birth weight of twins was higher than that of single twins ( $2.15 \pm 0.42$ vs. $2.79 \pm 0.22 \mathrm{~kg} / \mathrm{ewe})$, while body weight after lambing and ADG of lambs was not significantly different $(\mathrm{P}>0.05)$. This study concluded that the litter size affects the BCS of ewes and the birth weight of the lambs, so it was a suitable parameter for ewe selection.
\end{abstract}

Keywords: Body condition score, ewes performances, litter size, intensive management System.

\section{INTRODUCTION}

Sheep are one of the small ruminant livestock commodities generally kept by smallholder farmers, sheep can be maintenance easily and prolific in lambing. The sheep management level of success can be measured from productivity, such as the fertility level of ewes in the prolific ability to lambing. The number of offspring or litter size is influenced by the interaction of genetic and environmental factors. Litter size can be limited by ovulation rate, uterine capacity, age at first lambing, parity, mortality of pre-weaning lamb and ewe's body condition. Environmental factors which include feed and maintenance management can support the ewe's productivity. The quality and quantity of feed affect the ewe's reproduction [1].

The requirement for lactating ewes is higher to fulfil the basic needs and milk production. Nutrient intake during lactation can maintain ewe's body weight and
BCS 2.5-3.0 which affect the growth rate of lamb until weaning $[2,3]$. The growth of pre-weaned lamb is mostly from milk consumption. In the terms of ewe's milk production is less than optimal, it will have an impact on the lamb's growth rate. According to [4] a single litter size type has a greater chance of achieving weaning weights than twin litter sizes, in that there is no competition in consuming milk according to the lamb's needs. This study was conducted to determine the effect of litter size on the performance of lactating ewes.

\section{MATERIAL AND METHODS}

The study was carried out from August 2020 to March 2021, the rearing was located at Mendo Galak Farm, Yogyakarta. Using 20 DET-Garut composite sheep, 2-3 years old and 4 months gestation. The ewes were divided into two groups at parturition based on single and twin litter sizes. Sheep were kept in individual cages with a 
size of $\left(1 \times 1.1 \mathrm{~m}^{2}\right)$, equipped with feeders and drinking place. The feed had been given each day the same feed for 1 month postpartum. Ewes were fed 3\% of body weight (dry matter) with a proportion of $50 \%$ dry water spinach (Ipomea reptans) and 50\% concentrate KJUB Puspetasari F31, the nutrient content of the feed was shown in Table 1. Feeding was carried out twice a day at 07.00 and 15.00 in another way the drinking water was provided ad-libitum. Measurement of feed consumption was carried out by weighing the feed given and the rest for one month, adjusted to exactly one month after lambing. Samples of feed and feed residues were analyzed in the Forage Animal Feed laboratory, UGM.

Table 1. Nutrient content of feed (\%)

\begin{tabular}{|c|c|}
\hline Nutrient contents & Value \\
\hline Dry matter & 86.94 \\
\hline Crude protein* & 12.47 \\
\hline Crude fiber & 19.88 \\
\hline Crude fat & 3.55 \\
\hline Ash & 11.49 \\
\hline Organic matter & 88.51 \\
\hline Total digestible nutrient ${ }^{\star *}$ & 60.00 \\
\hline
\end{tabular}

Analysis at forage and pasture science laboratory,

Animal Science UGM

*Analysis at BPMSP, Agriculture Ministry

**Result based on Hartadi et al. (1980) formulation

BCS was rated on ewes at 4 months gestation, parturition, and 1 month postpartum. The score scale was 1 (thin) - 5 (obese) through observation and palpation of the spinous processes and transverse processes to assess body condition [5]. The following was how to assess ewe's BCS through palpation as shown in Figure 1.

The data observed included feed consumption and ewe's performance such as body weight, BCS and ADG of lambs. Feed consumption is calculated from the amount of feed given minus the remaining feed. Nutrient consumption measured was dry matter (DM), crude protein $(\mathrm{CP})$, and Total Digestible Nutrients (TDN). ADG is obtained from weighing which is carried out once a month, in the morning before fed, then the final weight is reduced by the initial weight divided by the maintenance time.

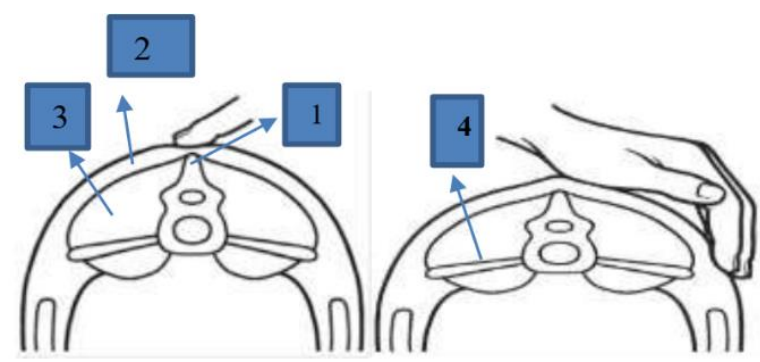

Figure 1. BCS assessment by palpation

Description: Prosessus spinosus

Fat

Muscle

Prosessus transversus

The research data obtained were analysed by one-way analysis of variance (one-way ANOVA), if the results were significant $(\mathrm{P}<0.05)$ followed by Duncan's New Multiple Range Test (DMRT) with the help of Statistical Product and Service Solution (SPSS ver. 22). Data were analysed to see differences between single and twin litter size groups.

Table 2. Nutrient balance of ewes with different litter size

\begin{tabular}{|c|c|c|}
\hline \multirow{2}{*}{ Variable } & \multicolumn{2}{|c|}{ Litter size } \\
\hline & Single & Twin \\
\hline Body weight $(\mathrm{kg})^{\mathrm{ns}}$ & $22.50 \pm 5.10$ & $20.21 \pm 2.88$ \\
\hline \multicolumn{3}{|c|}{ Nutrient intake (g/BW $\left.{ }^{0.75}\right)$} \\
\hline Dry Matter & $122.38 \pm 23.28^{a}$ & $158.14 \pm 28.48^{b}$ \\
\hline Crude Protein & $18.34 \pm 3.96^{a}$ & $23.94 \pm 3.55^{\mathrm{b}}$ \\
\hline $\mathrm{TDN}^{\mathrm{ns}}$ & $86.95 \pm 18.53$ & $110.29 \pm 21.77$ \\
\hline \multicolumn{3}{|c|}{ Nutrient requirement (g/BW0.75) } \\
\hline Dry Matterns & $308.71 \pm 50.60$ & $285.57 \pm 30.59$ \\
\hline Crude Protein ${ }^{\mathrm{ns}}$ & $33.03 \pm 5.41$ & $38.27 \pm 4.10$ \\
\hline TDNns & $182.14 \pm 39.85$ & $185.62 \pm 19.88$ \\
\hline \multicolumn{3}{|c|}{ Nutrient Balance (g/BW0.75) } \\
\hline Dry Matterns & $-186.32 \pm 63.61$ & $-127.44 \pm 40.82$ \\
\hline Crude Protein ${ }^{\text {ns }}$ & $-14.69 \pm 7.78$ & $-14.32 \pm 5.28$ \\
\hline TDNns & $-95.18 \pm 39.88$ & $-75.33 \pm 26.12$ \\
\hline
\end{tabular}

${ }^{\text {ns }}$ Non-significant; ${ }^{\text {a,b }}$ Different superscript in the same row shows significant result $(\mathrm{P}<0.05)$ 


\section{RESULTS AND DISCUSSION}

\subsection{Ewe's Nutrient Intake}

Nutrient consumption, nutrient requirements and nutrient balance were shown in Table 2. Nutrient requirements of lactating ewes are 3\% dry matter of body weight, for ewe's single litter size required $10.7 \% \mathrm{CP}$ and 59\% TDN. While the need for twin litter size lactating ewe required $13.4 \% \mathrm{CP}$ and $65 \%$ TDN from dry matter [6]. The consumption of dry matter and protein was significantly different between groups $(\mathrm{P}<0.05)$. This was a balance of protein levels as a stimulant for microbial growth in the rumen. [7] Synchronizing the availability of glucose from carbohydrates as energy and peptides in the form of protein nitrogen in the rumen increases microbial activity and rumen microbial protein synthesis. The results of this study were higher than [8] with the average consumption of local lactating ewe was DM $66.77-70.56 \mathrm{~g} / \mathrm{BW}^{0.75}$ and CP 10.82-17.61 g/BW ${ }^{0.75}$.

Consumption of ewe's twin litter size was higher than single litter size, however entire ewe's nutrient balances showed negative results. Increased nutrient requirements of ewe with single and twin litter sizes trigger a negative energy balance that occured during the final third of gestation (75\% foetus growth) and 30 days of early lactation. Metabolic development and use of the energy of ewe's body reserves followed a pattern that matches litter size [9]. The higher litter size then it would be higher ewe's nutrient requirements to get energy balance.

\subsection{Ewe's Performance}

The reproductive performance of ewe at different litter sizes was presented in Table 3. Ewe body weight, lamb body weight and ADG of lamb were not significantly different between litter sizes $(\mathrm{P}>0.05)$. According to [10] ewe's body weight and BCS there were not related with weaning weight. [3] stated that the achievement of individual weaning weight and ADG from nutrient intakes. However, according to [11] ewe's body weight, ADG of lamb, milk production and quality of milk composition were influenced by heavier ewe.

The results of the study on BCS of gestation ewes, one month lactation and birth weight of lamb on litter size differences were significantly different $(\mathrm{P}<0.05)$. BCS was a reflection of the nutritional status of livestock which indicate changes in the thickness of adipose tissue and subcutaneous fat as body reserves. As the mobilization of ewe's energy reserves during early lactation was associated with a decrease in BCS, but had no effect on body weight. The use of body reserves was associated as an adaptation of ewe to support the nutritional intake needs of lamb in the form of milk. Increased NEFA mobilized from adipose tissue responds to compensatory mechanisms, to balance energy deficit to support milk production [9].

Table 3. Reproductive performance of ewes in different litter size.

\begin{tabular}{|c|c|c|}
\hline \multirow{2}{*}{ Variable } & \multicolumn{2}{|l|}{ Litter size } \\
\hline & Single & Twin \\
\hline \multicolumn{3}{|l|}{ Ewes body weight $(\mathrm{kg})$} \\
\hline Gestation ${ }^{\mathrm{ns}}$ & $24.65 \pm 4.60$ & $23.35 \pm 2.07$ \\
\hline Parturition ${ }^{\text {ns }}$ & $22.51 \pm 4.48$ & $19.92 \pm 1.01$ \\
\hline 1 month of lactation ${ }^{\text {ns }}$ & $21.76 \pm 4.53$ & $20.49 \pm 4.82$ \\
\hline \multicolumn{3}{|l|}{ Ewes body condition score } \\
\hline Gestation & $3.12 \pm 0.24^{b}$ & $2.83 \pm 0.29^{a}$ \\
\hline Parturition $^{\text {ns }}$ & $2.75 \pm 0.26$ & $2.50 \pm 0.0$ \\
\hline 1 month lactation & $2.82 \pm 0.25^{b}$ & $2.50 \pm 0.00^{a}$ \\
\hline \multicolumn{3}{|l|}{ Body weight and ADG of lamb } \\
\hline Birth weight (kg/ewe) & $2.15 \pm 0.42^{\mathrm{a}}$ & $2.79 \pm 0.22^{b}$ \\
\hline 1 month $(\mathrm{kg} / \mathrm{ewe})^{\mathrm{ns}}$ & $6.18 \pm 1.12$ & $6.83 \pm 0.54$ \\
\hline ADG $(g / e w e)^{n s}$ & $137.31 \pm 29.67$ & $135.33 \pm 13.78$ \\
\hline
\end{tabular}

${ }^{n s}$ non-significant

${ }^{a, b}$ Different superscript in the same row shows significant result $(\mathrm{P}<0,05)$ 
Insulin played a key role in the homeostatic mechanism of energy status which was negatively correlated with negative energy balance [12].

Birth weight was an important trait in the survival and growth of lamb during pre-weaning [13]. According to [14] there was an effect of ewe's BCS with lamb's birth weight, BCS 2.0 had lower birth weight and weaning weight of lambs compared to BCS 2.5-3.0 ewes.

\section{CONCLUSSION}

The concludes that the differences in litter size affect the performance of ewe, especially the decrease in BCS in the same feed and birth weight of lamb. It is necessary to improve the quality of feed for low BCS ewe and twin litter size in order to optimize ewe's reproduction.

\section{ACKNOWLEDGMENTS}

Thank you to Universitas Gadjah Mada through the 2021 Final Project Recognition program which has partially supported the financing of research, seminars and publications. Also the owner of Mendo Galak Farm who has provided facilities for research purposes.

\section{REFERENCES}

[1] N. Teti, R. Latvia, I. Hernaman, B. Ayuningsih, D. Ramdani, Siswoyo, The Effect of Protein to Energy Ratios on Nutrient Digestibility of Female Garut Sheep's Diets, Jurnal Ilmu dan Teknologi Peternakan, vol. 6, 2018, pp. 97-101. DOI: https://doi.org/10.20956/jitp.v6i2.6355

[2] R.A. Corner-Thomas, R.E. Hickson, S.T. Morris, P.R. Kenyon, The influences of live weight and body condition score of ewe lambs from breeding to lambing on the live weight of their singleton lambs to weaning, Small Ruminant Research, vol. 119, Elsevier B. V., 2014, pp. 16-21. DOI: https://doi.org/10.1016/j.smallrumres.2014.01.00 $\underline{8}$

[3] R.A. Corner-Thomas, R.E. Hickson, S.T. Morris, P.J. Black, A.L. Ridler, K.J. Stafford, P.R. Kenyon, Effects of body condition score and nutrition in lactation on twin-bearing ewe and lamb performance to weaning, New Zealand Journal of Agricultural Research, vol. 52, England, Taylor and Francis, 2014, pp. 156-169. DOI:

https://doi.org/10.1080/00288233.2014.987401

[4] I. Boujenane, I.T. Diallo, Estimates of genetic parameters and genetic trends for pre-weaning growth traits in Sardi sheep, Small Ruminant Research, vol. 146, Elsevier B. V., 2017, pp. 6168.

DOI: https://doi.org/10.1016/j.smallrumres.2016.12.00 $\underline{2}$

[5] J. Thompson, H. Meyer, Body condition scoring of sheep, Oregon State University Extension Service, U.S., Oregon countries, 1994, pp. 61-68.

[6] National Research Council, Nutrient requirements of sheep table of contents national research council nutrient requirements of sheep $6^{\text {th }}$ revised ed., Livestock Research for Rural Development, National Academy Press, Washington, D.C., 1985.

[7] B. Klein, Cunningham's textbook of veterinary physiology $6^{\text {th }}$ ed., Elsevier Inc, St. Louis, Missouri, 2020, pp. 1-645

[8] I.W. Mathius, D. Sastradipradia, T. Sutardi, A. Natasasmita, L.A. Sofyan, D.T.H Sihombing, Strategic study on energy-protein requirements for local sheep: 5. Ewes during lactation phase, Jurnal Ilmu Ternak dan Veteriner, vol. 8, Indonesian Agency of Agricultural Research and Development, 2003, pp. 26-39. DOI: https://dx.doi.org/10.14334/jitv.v8i1.370

[9] E.G. Garcia, A. Tesniere, S. Camous, F. Bocquier, F. Barillet, P. Hassoun, The effects of parity, litter size, physiological state, and milking frequency on the metabolic profile of Lacaune dairy ewes, Domestic Animal Endocrinology, vol. 50, Elsevier B. V., 2015, pp. 32-44. DOI: https://doi.org/10.1016/j.domaniend.2014.07.001

[10] P.R. Kenyon, S.J. Pain, P.G. Hutton, C.M.C. Jenkinson, S.T. Morris, S.W. Peterson, H.T. Blair, Effects of twin-bearing ewe nutritional treatments on ewe and lamb performance to weaning, Animal Production Science, vol. 51, Australia, Csiro Publishing, 2011, pp. 406-415. DOI: https://doi.org/10.1071/AN10184

[11] K.H. Sultan, The effect of body weight and litter size on some productive parameters and milk components of sheep under semi - intensive breeding, Mesopotamia Journal of Agriculture, vol. 47, Iraq, University of Mosul, 2019, pp. 1524

DOI:

http://dx.doi.org/10.33899/magrj.2019.126115.1 $\underline{009}$

[12] Y. Chilliard, A. Ferlay, Y. Faulconnier, M. Bonnet, J. Rouel, F. Bocquier, Adipose tissue metabolism and its role in adaptations to undernutrition in ruminants, Proceedings of the Nutrition Society, vol. 56, U.K., Cambridge University Press, 2000, pp. 127-134. DOI: https://doi.org/10.1017/S002966510000015X 
[13] M. Ghasemi, P. Zamani, M. Vatankhah, R. Abdoli , Genome-wide association study of birth weight in sheep, Animal, vol. 13, U.K., Cambridge University Press, 2019, pp. 1797-1803. DOI: https://doi.org/10.1017/S1751731118003610

[14] V. Sejian, V.P. Maurya, S.M.K. Naqvi, D. Kumar A. Joshi, Effect of induced body condition score differences on physiological response, productive and reproductive performance of Malpura ewes kept in a hot, semi-arid environment, Journal of Animal Physiology and Animal Nutrition, vol. 94, U.S., New Jersey, Wiley Online Library, 2010, pp. 1797-1803. DOI: https://doi.org/10.1111/j.14390396.2008.00896.x 